\title{
BIOCHEMICAL INDICATORS OF NEPHROTOXICITY IN BLOOD SERUM OF RATS TREATED WITH NOVEL 4-THIAZOLIDINONE DERIVATIVES OR THEIR COMPLEXES WITH POLYETHYLENE GLYCOL-CONTAINING NANOSCALE POLYMERIC CARRIER
}

\author{
L. I. KOBYLINSKA', D. Ya. HAVRYLYUK ${ }^{1}$, N. E. MITINA ${ }^{2}$, A. S. ZAICHENKO', \\ R. B. LESYK ${ }^{1}$, B. S. ZIMENKOVSKY1, R. S. STOIK ${ }^{3}$ \\ ${ }^{1}$ Danylo Halytsky Lviv National Medical University, Ukraine; \\ e-mail: stoika@cellbiol.lviv.ua; \\ ${ }^{2}$ Lviv Polytechnic National University, Ukraine; \\ ${ }^{3}$ Institute of Cell Biology, National Academy of Sciences of Ukraine, Lviv
}

\begin{abstract}
The aim of this study was to compare the effect of new synthetic 4-thiazolidinone derivatives (potential anticancer compounds denoted as 3882, 3288 and 3833) and doxorubicin (positive control) in free form and in their complexes with synthetic polyethylene glycol-containing nanoscale polymeric carrier on the biochemical indicators of nephrotoxicity in blood serum of rats. The concentration of total protein, urea, creatinine, glucose, ions of sodium, potassium, calcium, iron and chloride was measured. It was found that after injection of the investigated compounds, the concentration of sodium cations and chloride anions in blood serum was increased compared with control (untreated animals). Doxorubicin's injection was accompanied by a decrease in the concentration of iron cations. The concentration of total protein, urea and creatinine decreased under the influence of the studied compounds. Complexation of these antineoplastic substances with a synthetic polymeric nanocarrier lowered the concentration of the investigated metabolites substantially compared to the effect of these compounds in free form. The normalization of concentration of total protein, urea and creatinine in blood serum of rats treated with complexes of the studied compounds with the polymeric carrier comparing with increased concentration of these indicators at the introduction of such compounds in free form was found.
\end{abstract}

Key words: 4-thiazolidinone derivatives, doxorubicin, nanoscale polymeric carrier, nephrotoxicity, concentration of metabolites, blood serum of rats.

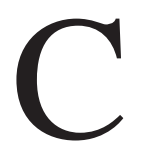
hemotherapy is one of the most important remedies in treatment of malignant tumors [1]. However, despite the fact that maximum toxic effect of chemotherapeutic agents is directed at the tumor cells, the use of most of these agents causes a number of adverse side effects towards cells of normal tissues and organs [3]. During the anticancer chemotherapy, the most effective are the drugs destructive for rapidly proliferating cells such as hematopoietic progenitor cells, intestinal epithelium, hair follicles and cells of other tissues with high regenerative activity, in particular the immune cells [1]. That is why, the biosafety of drug therapy is an important issue at using anticancer drugs.

Alongside with hepato-, cardio- and neurotoxicity, the nephrotoxicity, namely the ability of chemicals to cause structural and functional disorders in kidney morphology and functions, is one of the most important manifestations of negative side effects of the anticancer drugs [2-5]. Nephrotoxicity is primarily associated with lesions in proximal, rarely distal tubules and glomeruli of the kidney $[5,6]$. A violation of hemodynamics in glomeruli, toxic effect on tubular epithelium, inflammation, nephropathy, crystalluria, rhabdomyolysis and microangiopathy, immune and autoimmune reactions are the most common pathophysiological mechanisms of drug nephrotoxicity [5, 6]. Adverse nephrotoxic reaction to drugs may have both renal (at the level of glomerular filtration, tubular reabsorption and secretion), and pre- and postrenal character. High level of blood supply and big length of tubular apparatus 
caused a prolonged contact of toxins and their metabolites with the endothelial cells of the blood vessels and the epithelium of kidney tubules.

Nephrotoxicity is inherent to a significant number of drugs $[1,5,6]$. According to literature data, about $20-30 \%$ of reported cases of the acute renal failure and almost a third of cases of chronic renal failure resulted from the impact of chemical agents, including those of medicinal origin. Therefore, nephrotoxicity is also a limiting factor that stints conduction of adequate cytostatic therapy in the oncological practice $[5,6]$. Lesions of renal tubules are caused by the reabsorption of high doses of cytostatics and their metabolites from the glomerular filtrate. The nephrotoxic effect of cytostatics manifests primarily in reducing creatinine clearance which, in turn, increases the duration of circulation in the blood factors that are excreted or metabolized by the kidney. All that leads to a lengthening of the duration of drugs' effect on organs and tissues and, consequently, enhances all types of toxic effect of the cytotoxic drugs. [5]

In medical practice, antibiotics of the anthracycline series, especially effective in cancer chemotherapy, are widely used. Doxorubicin is one of the most commonly used anthracycline antitumor antibiotic. The mechanism of its biological action is associated with the induction of apoptotic death of tumor cells resulted from DNA destruction and with inhibition of cell proliferation [1]. Meanwhile, the anthracycline antibiotics cause negative side effects accompanied by lesions of various organs and violation of their functioning. The cardiotoxicity is one of the most pronounced side effects of doxorubicin, and numerous studies are devoted to that pathology. However, the effect of doxorubicin towards other organs and tissues, including the kidney remains poorly understood $[3,4]$. The introduction of cytostatics causes a damage to blood vessels and structures of the kidney which leads to hemolytic and uremic syndrome. Nephrotoxic effect of cytostatics manifests in the increase of the level of creatinine in blood serum that appears due to a decrease in the intensity of glomerular filtration in kidney [6]. Thus, the increase of urea and creatinine in serum is an important clinical sign of nephrotoxicity $[5,6]$. One injection of doxorubicin in rats leads to proteinuria and glomerular kidney damage. Renal toxicity caused by doxorubicin, at least partly, is evoked by the oxidative stress subsequently leading to the inflammation in kidney [6].
It is known that a majority of cytostatics are excreted by the kidney and some of them (cisplatin, tiophosphamide, methotrexate and bleomycin) are metabolized in it. The main mechanism of the negative effect of anticancer drugs in kidney is related to their direct cytotoxicity and the autoimmune nature of complications [5-7]. A degree of toxic damage of kidney caused by the cytostatics depends on drug dose, concomitant pathology of the kidney, creatinine clearance, and urine output. High accumulation of cisplatin in kidney tissue, its dose-dependent and cumulative nephrotoxicity are typical of this drug. During the administration of specific anticancer drugs, nephrotoxicity is manifested differentialy: cisplatin causes tubular necrosis, mitomycin - glomerular vasculitis, phosphamid - proximal tubular defect, hematuria, and chemical cystitis, and cyclophosphamide - acute hemorrhagic cystitis. A considerable nephrotoxicity is inherent in the anticancer drugs among which platinum-containing drugs are the most nephrotoxic ones. Thus, a combination of the irinotecan and cisplatin used to treat cancer patients was accompanied by kidney lesions in 25\% of cases. That requires a reduction of drug dose at different stages of treatment. Besides, it was established that a combined effect of docetaxel and cisplatin caused nephrotoxic changes in $21 \%$ of cases, and etoposide - in 23\%. However, a combination of drugs without platinum also caused big kidney damage [1, 7]. While administering cisplatin, a significant lowering of glomerular filtration with increase of creatinine in blood serum and decrease of effective renal plasma flow were noted [1].

According to the International Program of Therapeutic Development at the National Cancer Institute (Bethesda, USA) in vitro cytotoxic effect of new synthetic derivatives of 4-thiazolidinone (compounds denoted as 3882, 3288 and 3833) towards cells of 60 different lines of human tumors has been studied. The ratio that determines the number of cells under the effect of synthesized compounds relative to the number of cells in the absence of such effect was calculated. The number of cells was measured using sulforodamine B method with 5-fluorouracil and doxorubicin used as standards. The results were presented as a percentage of cells in control (without addition of investigated factors) [6, 11]. Compounds 3882, 3288 and 3833 were used in different concentrations. According to the results of previous studies of the antitumor activity of 4-thiazolidinone derivatives, including pyrazoline-substituted, these pyrazoline-tiazolidynone-indoline-conjugates were 
suggested to be the most promising for further use as anticancer agents [2-4, 12].

The aim of this study was to evaluate the toxic effect of three derivatives of 4-thiazolidinones (3288, 3882, 3833) and doxorubicin (positive control) in rats. The impact of free forms of these compunds was compared with their effect after complexation with a polymeric nanoscale carrier (PC), synthesized on the copolymer of unsaturated peroxide-2-tertbutylperoxy-2-methyl-5-hexene-3-yne (VEP) and glycidyl methacrylate (GMA) with conjugated polyethylene glycol (PEG) side chains [13]. Biochemical indicators that determine functional condition of kidney, namely concentration of total protein, urea, creatinine and glucose, as well as the concentration of sodium ions, potassium, iron and chloride in blood serum of rats were used as criteria for such comparison.

\section{Materials and Methods}

The research was conducted on nonlinear white laboratory sexually mature male rats of 200-220 g weight that were fed standard fodder in animal facility boxes with an appropriate lighting and temperature conditions [14, 15].

All manipulations with animals were carried out in accordance with the European Convention for the Protection of Vertebrate Animals used for Experimental and Other Scientific Purposes (Strasbourg, 1986), and in accordance with the Law of Ukraine On Protection of Animals from Cruelty [15, 16]. The research protocol followed a Decree No 944 of the Ministry of Health Protection of Ukraine issued on 14.12.2009 "Establishing the order of conduct for preclinical studies of pharmaceutical substances and expert evaluation of materials from preclinical studies of pharmaceutical substances" and current methodological recommendations $[14,16,17]$.

Compounds denoted as 3882, 3288, 3833 were synthesized at the Department of Pharmaceuticals, Organic and Bioorganic Chemistry at Danylo Halytsky Lviv National Medical University [10]. Doxorubicin (Arterium, Ukraine) was of standard pharmacy distribution. The polymeric carrier was synthesized at the Department of Organic Chemistry at Lviv National Polytechnic University [18]. In the core of that carrier, there is a water-soluble comb-like polymer poly-VEP-GMA-PEG with a backbone of the copolymer based on unsaturated VEP and GMA with attached PEG side chains [7, 19].
In vivo experiments were conducted on rats for 20 days with daily injection of compounds 3882, 3288,3833 or their complexes with polymeric carrier. There were 10 groups of 20 animals each used in the study: 1 - control group (intact animals); 2 - group with doxorubicin injections; 3, 4 and 5 - experimental groups in which animals received injections of compounds 3288, 3882 and 3833, correspondingly; 6 - experimental group in which animals received injections of complex of the doxorubicin with the polymeric carrier; 7, 8, 9 - experimental groups in which animals received injections of complexes of the polymeric carrier with compounds 3288, 3882 and 3833, correspondingly; 10 - group injected with the polymeric carrier only.

All compounds were administered daily by the intraperitoneal injections once per day after fasting. The experiment lasted for 20 days. The initial dose of investigated compounds was calculated as $10 \%$ of the lethal dose $\left(\mathrm{LD}_{50}\right)$ for each compound in vivo $[3,4,11,12]$. The initial dose for the doxorubicin was $5.5 \mathrm{mg} / \mathrm{kg}$, for the compounds 3882 and 3833 $10.7 \mathrm{mg} / \mathrm{kg}$, and for the compound $3288-24.3 \mathrm{mg} /$ $\mathrm{kg}$. The doses were gradually elevated 1.5 times per 4 days in order to achieve a cumulative effect. Complexes of investigated cytotoxic drugs with the polymeric carrier were administered as a solution with a ratio of drug to polymer as 1 to 30 .

On the $10^{\text {th }}$ and $20^{\text {th }}$ day of experiment, the rats were decapitated under general thiopental anesthesia. The obtained blood was used to receive serum in which concentration of protein, urea, creatinine, glucose, sodium cations, calcium, iron and chloride anions was measured. For defining these biochemical indicators, standard test kits for the automatic biochemical analyzer Humalyzer 3000 (Germany) were used [20].

In order to study biodegradability and clearance of the applied PC in the organism of treated experimental rats, the urine and stool were examined for the presense of the constituents of this PC. Urine was collected for 1 day from rats after a single injection of $2 \mathrm{ml}$ of pure PC. The isolation of the PC constituents from urine was performed by means of liquid extraction in the aqueous phase, since PC is insoluble in the organic solvents. Fractionation of water extracts was performed by $20 \%$ solution of the sulfanilic acid and fractionation of urine - by $20 \%$ solution of $\mathrm{CaCl}_{2}$. Evaporation was performed in a water bath. $1 \mathrm{ml}$ of aqueous phase was applied on the starting line of the chromatographic plate Sorbfil. 
Acetone-dioxane $(4: 1)$ mixture was shown to be the most efficient system at thin layer chromatography. After chromatography, the plates were developed by Dragendorff's reagent (freshly prepared solution of diphenylcarbazone in chloroform) and aqueous solution of the potassium iodine platynate.

The statistical analysis of the obtained results was carried out by using generally accepted methods for calculating of variance with MS Excel software for Student's $t$-test. The difference was considered to be statistically significant at $P<0.05$.

\section{Results and Discussion}

Earlier, we demonstrated that immobilization by novel polymeric carrier of doxorubicin and experimental anticancer compounds 3882, 3288 and 3833 possessing high general toxicity in rats mitigates their toxic effects that was evident as normalization of specific biochemical indicators of the cardio- [3] and hepatotoxicity [4]. Here such protective effect of drug complexation with the carrier was shown regarding the nephrotoxicity evoked by the injection of doxorubicin and 4-thiazolidinone derivatives.

Kidney plays a crucial role in maintaining fluid, electrolyte and acid-base balance, and thus, toxic lesions in this organ are always accompanied by disorders in metabolism of electrolytes, water, and low molecular weight metabolites that are excreted by kidney. Within 20 days of the experiment, we did not observe changes in the appearance, skin condition, behavior, appetite and body weight of the experimental rats of $3-9^{\text {th }}$ groups compared to the control group. Only in the second group of animals treated with doxorubicin, a significant reduction in body weight, changes in skin, general weakness and low activity were noticed. These changes could be a result of general toxic influence of doxorubicin on trophic processes.

Administration of the doxorubicin for 10 days led to $26 \%$ decline in protein concentration in blood serum, whereas doxorubicin-PC complex (6 $6^{\text {th }}$ group) did not significantly affect protein concentration compared to the $2^{\text {nd }}$ group of animals (Table 1). Similar changes were observed when measuring creatinine concentration in blood serum of rats in the $2^{\text {nd }}$ and $6^{\text {th }}$ groups: administration of doxorubicin led to $24 \%$ reduction of its concentration, while under the influence of free $\mathrm{PC}$ or its complex with doxorubicin creatinine remained at control level (Table 1). A decrease in urea concentration under the influence of doxorubicin was quite significant. It is known that urea is synthesized exclusively by the hepatocytes, and it is the main product in the mechanisms of neutralization of toxic ammonia. Thus, urea is considered to be an indicative biochemical marker of liver lesions [2, 4]. We found that urea concentration was reduced by $60 \%$ after 10 days of doxorubicin administration, while application of drug complex with the PC resulted in a decrease of urea by only $27 \%$. These data suggest a protective effect of the nanocarrier not only in hepatocytes, but also towards kidney cells that are involved in urea removal from the body (Table 1). Free PC did not significantly affect urea concentration in blood serum of treated rats (Table 1). Under the influence of doxorubicin glucose concentration in blood increased by $40 \%$ ( $2^{\text {nd }}$ group), while in rats of $6^{\text {th }}$ group glucose level did not exceed normal value (Table 1). Sodium cations and chlorine anions are the major extracellular ions that regulate $92 \%$ of total osmolarity of blood plasma. Administration of the doxorubicin resulted in a significant increase in concentration of the ions: $\mathrm{Na}^{+}-2.5$ times, $\mathrm{Cl}^{-}-$by $63 \%, \mathrm{Ca}^{2+}-$ by $45 \%$ (Table 1 ). The application of doxorubicin in complex with the PC reversed the concentration of sodium ions in blood serum to the normal values, meanwhile the concentration of chloride anions decreased slightly, still remaining at the elevated levels (56\%). The effect of doxorubicin in combination with the nanoscale polymeric carrier resulted in normalization of concentration of iron and calcium ions, as compared with their standard parameters (Table 1).

Thus, 10 days administration of doxorubicin to rats leads to a reduction in total protein, urea, creatinine, iron cations and also results in an increase of concentration of glucose, sodium and chlorine ions in blood serum of the experimental animals. The application of doxorubicin in combination with the PC reversed the values of total protein, urea, creatinine, ions of sodium, calcium and iron in blood serum of rats to normal values compared with the $2^{\text {nd }}$ group of animals treated with free form of the drug (Table 1).

In the $3^{\text {rd }}$ group of animals which were injected with a synthetic compound 3288, a $25 \%$ reduction of total protein in blood serum after 10 days of use was observed, while the complex of this compound with the PC ( $7^{\text {th }}$ group) normalized protein level (Table 1, 2). After injection of the anticancer drugs for 20 days, the concentration of urea and creatinine decreased, demonstrating toxic effect of the experimental drugs. However, after the introduction of 


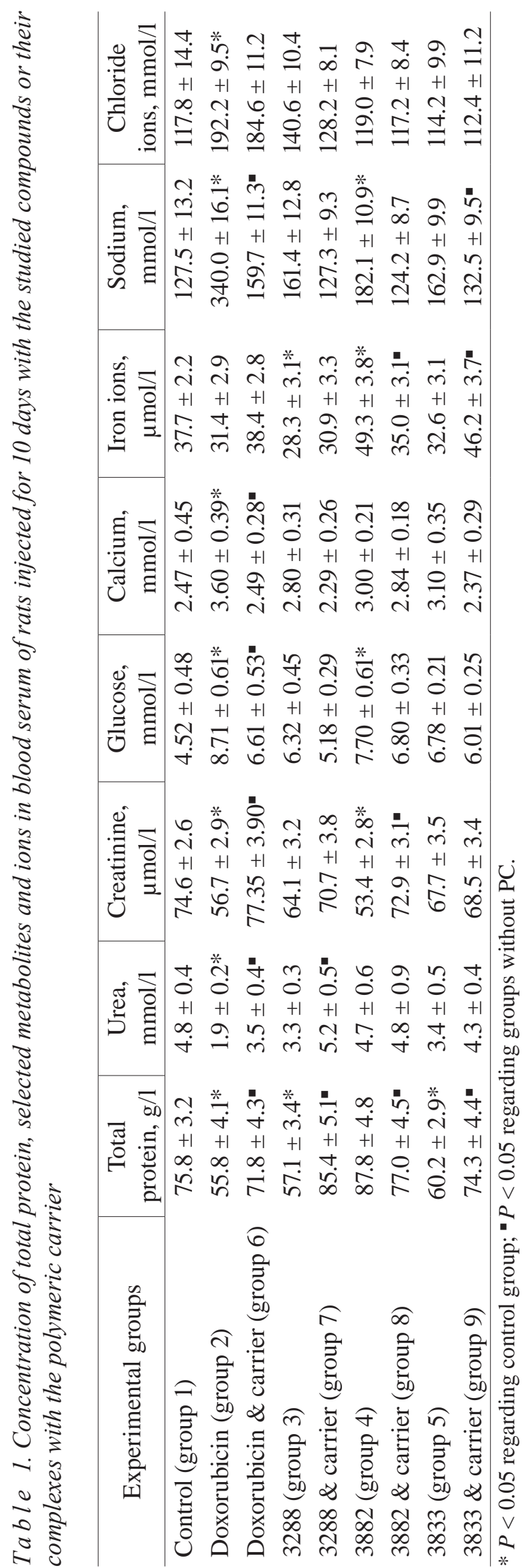

complex of compound 3288 with the NC ( $7^{\text {th }}$ group), the concentration of these metabolites did not change beyond the normal level.

We also observed 2-fold increase in concentration of sodium ions and $35 \%$ reduction of concentration of iron ions in the $3^{\text {rd }}$ group of animals within 20 days after the beginning of application of the compound 3288 (Table 2). The injection of 3288 in complex with the PC ( $7^{\text {th }}$ group) led to normalization of concentration of sodium and iron ions compared to the normal values. Thus, the compound 3288 showed weak nephrotoxic effect in rats under conditions of daily injection, although more distinct changes were found after 20-day application of that drug ( $3^{\text {rd }}$ group). The application of complex of compound 3288 with the PC normalized biochemical parameters of the nephrotoxic action of this derivative in the $7^{\text {th }}$ group of experimental rats.

The rats of the $4^{\text {th }}$ group were treated with the compound 3882 for 20 days. Under the 10-day treatment with this compound, creatinine concentration reduced by $37 \%$, and the concentration of iron ions increased by $30 \%$ (Table 1 ). Whilst 20-day administration of that drug led to $20 \%$ decrease of total protein in blood serum, urea concentration decreased by $45 \%$, creatinine - by $21 \%$, ions of iron - by $40 \%$. An increase in concentration of glucose by $40 \%$, calcium ions $-35 \%$, sodium ions $-43 \%$ and chlorine ions $-21 \%$, compared to these indicators in animals of the control group was found (Table 1). After 20 day application of the compound 3882 in complex with the PC, the above mentioned parameters were within normal limits and only the total protein level in blood serum of the $8^{\text {th }}$ group after 10 days of injection of the complex increased by $16 \%$ (Table 1, 2).

The rats of the $5^{\text {th }}$ experimental group received the synthetic compound 3833. According to the results of our previous studies [8,9], this compound was characterized by the most pronounced cytotoxic effect and possessed the highest toxic effect in rats compared to the effect of other 4-thiazolidinone derivatives. As expected, the drug 3833 demonstrated the highest nephrotoxicity among the 4-thiazolidinone derivatives used in this study. The indicators of nephrotoxicity of that compound were close to doxorubicin's ones. The total protein in blood serum was reduced by $20 \%$ under the effect of the compound on the $10^{\text {th }}$ day of treatment (Table 1 ), and on the $20^{\text {th }}$ day, that reduction reached 35\% (Table 2). Delivery of the compound 3833 in complex with the PC did not significantly affect the level of total protein in 


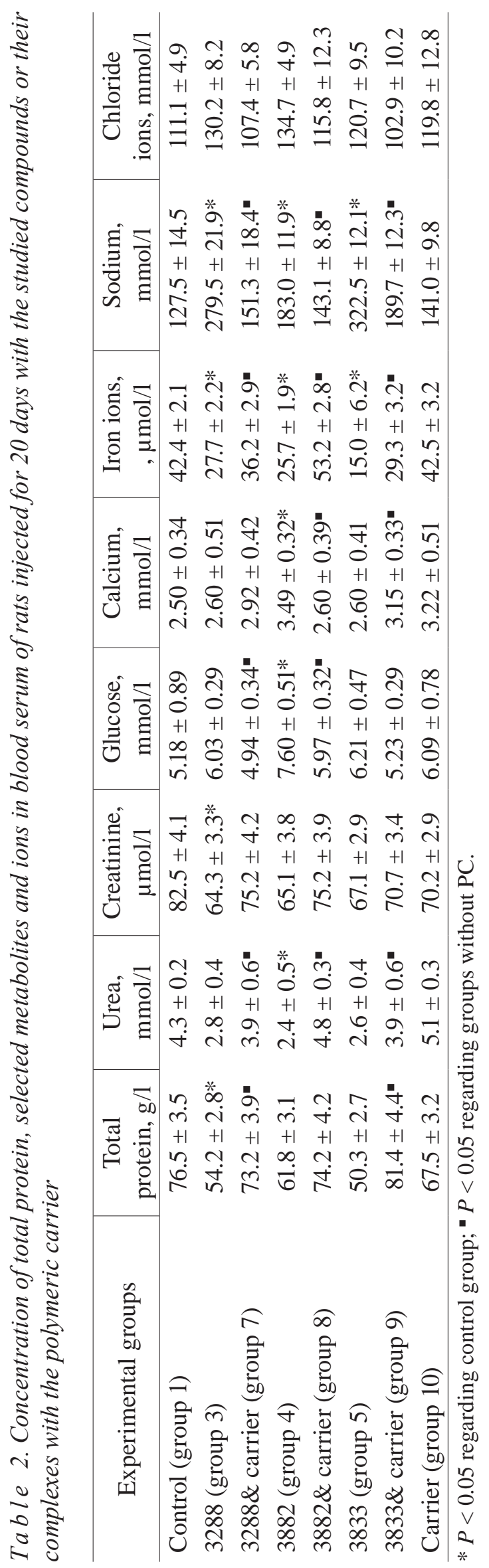

blood serum of rats of the $9^{\text {th }}$ group. Introduction of the experimental antitumor compound 3833 did not affect the concentration of glucose, calcium and chloride ions. These indicators remained within the normal levels after 20-day administration of both the compound 3833 ( (th $^{\text {th }}$ group) and its complex with the PC ( $9^{\text {th }}$ group). Although, the concentration of urea and creatinine in blood serum of rats had a tendency to decrease, it did not exceed the normal values. The concentration of iron ions was decreased by $75 \%$ on the $20^{\text {th }}$ day of application of the compound 3833 (Table 2), whilst the introduction of this compound in complex with the PC reduced iron concentration only by $30 \%$ after 20 days ( $9^{\text {th }}$ group). The injection of the compound 3833 increased significantly the concentration of sodium ions. After 10 days of its introduction, $\mathrm{Na}^{+}$concentration was increased by $27 \%$ (Table 1), whilst on the $20^{\text {th }}$ day of its use that increase reached 2.5 times (Table 2). The complex of experimental anticancer drug with the PC did not change the concentration of sodium ions on the $10^{\text {th }}$ day of experiment and increased it by $48 \%$ after 20 days treatment.

The $10^{\text {th }}$ group of animals treated for 20 days with the free PC lacking conjugated anticancer compounds demonstrated that in blood serum concentration of total protein, urea, creatinine, glucose, ions of calcium and iron remained without substantial changes (Table 2), indicating the absence of a significant nephrotoxic effect of the polymer. Free PC had no effect on the concentration of sodium and chlorine ions in blood serum of the treated rats suggesting biosafety of this carrier used for delivery of anticancer drugs.

The content of constituents of the PC was examined in urine and stool of rats of the $10^{\text {th }}$ group treated with PC. To do that, thin-layer chromatography on the Sorbfil plate in acetone-dioxan $(4: 1)$ solvents was conducted. It was suggested that the PC is metabolized in liver tissue and its clearance is under the control of kidney. When estimating clearance of the PC in daily urine and faeces, we have defined that rat faeces contained $8-10 \%$ of the PC in native form, while urine $-20 \%$ in native form, $15-20 \%$ - as the VEP product, and $13-25 \%$ - as the PEG product. Liver tissue contained only traces of those products. Since all components of the PC - VEP, PEG and $\mathrm{PC}$ - were present in urine of the experimental animals, we suggest that clearance of the PC occured through the kidney. 
It is known that protein synthesis is one of the main functions of liver cells and a reduction of the total protein concentration in blood serum suggests liver dysfunction caused by the antitumor drug doxorubicin, as well as by the synthetic compounds 3288 and 3833. That demonstrates high hepatotoxicity of these drugs, as suggested earlier [16]. It should be noted that the application of the above mentioned complexes of experimental anticancer drugs in complex with the PC did not lead to changes in the level of total protein in blood serum of treated rats and that level remained within normal values. After 10day application of doxorubicin and compound 3882, the rats of the $2^{\text {nd }}$ and $4^{\text {th }}$ groups demonstrated a reduction in the level of urea and creatinine proving the hepatotoxic effect of these drugs, since urea is synthesized exclusively in the liver. After 20 days of treatment, a reduction in creatinine concentration under the influence of all investigated 4-thiazolidinones was noticed, but the amplitude of that decrease was significantly lower, that suggests much lower toxic effect of new synthetic anticancer compounds compared to the effect of the doxorubicin. Appropriate complexes of all used anticancer compounds with the PC did not change blood serum creatinine and urea compared with their normal levels suggesting a perspectiveness of using PC for reducing toxic effect of the anticancer drugs.

Iron is an essential substrate in synthesis of the hemoglobin; it is also involved in the DNA synthesis, acts in many oxidation-reduction reactions and detoxification of toxic substances in the liver [15]. A reduction of concentration of the iron ions in blood serum of the $3^{\text {rd }}$ (3288) and $5^{\text {th }}$ (3833) groups of experimental rats also might suggest its involvement in the detoxification processes. However, the levels of sodium and chlorine ions were the most revealing indicators of the nephrotoxic effect of the applied anticancer drugs. Their levels were rapidly growing in the $2^{\text {nd }}$ group subjected to 10 -day treatment with the doxorubicin and in the $3^{\text {rd }}$ and $5^{\text {th }}$ groups subjected to 20-day treatment with the compounds 3288 and 3833. $\mathrm{Na}^{+}$and $\mathrm{Cl}^{-}$ions stay mainly in the extracellular space regulating the osmotic pressure in blood and they are excreted by the kidney. Raising of the level of these ions may suggest a disturbance in the reabsorption in the proximal tubules and Henle's loop, as well as about a secretion of $\mathrm{K}^{+}$ions in exchange for $\mathrm{Na}^{+}$ions in the distal renal tubules.

Thus, the levels of total protein, urea, creatinine, glucose, ions of iron, calcium, sodium and chloride in blood serum of the experimental rats under the influence of investigated synthetic derivatives of the 4-thiazolidinone are characterized by a lower amplitude of changes comparing to the amplitude of these changes caused by the doxorubicin. Complexation of the synthetic compounds 3882, 3288 and 3833 with nanoscale PC significantly reduced the nephrotoxic effect of these compounds compared to such effect of their free forms. Probably, poorly soluble in water 4-thiazolidinone derivatives form soluble micellar complexes as conjugates with the NC, and staying in such conjugates these derivatives are protected from possible interaction with the extracellular substances. This allows them to retain stability in the body for a longer time and to be accumulated in the targeted tissue or organ without causing adverse negative side effect [19].

The higher antineoplastic activity of the synthetic derivatives of 4-thiazolidinone (compounds 3882, 3288 and 3833) towards 60 cultured human tumor cell lines positively correlated with higher toxic effects of these compounds in the body of the experimental rats. The doxorubicin possessing the highest anti-neoplastic activity, simultaneously has the highest overall toxic effects in the treated animals. All rats that were injected for 10 days with the doxorubicin died, while the introduction of compounds 3882, 3288 and 3833 did not cause such a lethal effect. These results make it possible to affirm that combining of the anticancer drugs with the polymeric nanocarrier reduces their overall toxic effect in the body of the experimental animals, including renal toxicity, compared with such effect of these substances in free form. The use of the PC for conjugation with drugs in the form of a stable watersoluble delivery systems reduces the level of indicators of the nephrotoxic effect of the anticancer drugs. 


\section{БІОХІМІЧНІ ПОКАЗНИКИ НЕФРОТОКСИЧНОСТІ У СИРОВАТЦІ КРОВІ ЩУРІВ ЗА ДІЇ НОВИХ ПОХІДНИХ 4-ТІАЗОЛІДИНОНІВ ТА ЇХНІХ КОМПЛЕКСІВ І3 ПОЛІЕТИЛЕНГЛІКОЛЬВМІСНИМ ПОЛІМЕРНИМ НАНОРОЗМІРНИМ HOCIEM}

Л. І. Кобилінська ${ }^{1}$, Д. Я. Гаврилюк ${ }^{1}$ Н. С. Мітіна ${ }^{2}$, О. С. Заіченко ${ }^{2}$ Р. Б. Лесик ${ }^{1}$, Б. С. Зіменковський, Р. С. Стойка

\section{${ }^{1}$ Львівський національний медичний університет імені Данила Галицького, Україна; e-mail: stoika@cellbiol.lviv.ua; \\ ${ }^{2}$ Національний університет «Львівська політехніка», Україна;}

${ }^{3}$ Інститут біології клітини НАН України, Львів

Основним завданням дослідження було порівняти вплив нових синтетичних похідних 4-тіазолідинонів (сполуки 3882, 3288 і 3833) i доксорубіцину (позитивний контроль) у вільному стані та в комплексі із синтетичним поліетиленглікольвмісним нанорозмірним носієм на біохімічні показники нефротоксичності у сироватці крові щурів. Для цього визначали вміст загального протеїну, глюкози, сечовини, креатиніну, катіонів натрію, кальцію, заліза та аніонів хлориду. Встановлено, що після введення усіх зазначених чинників у сироватці крові експериментальних тварин значно зростає порівняно 3 контролем концентрація іонів натрію і хлоридів, а також глюкози, а за дії доксорубіцину - ще й катіонів кальцію. Разом $з$ тим, за таких умов відбувалося вірогідне зниження концентрації загального протеїну, сечовини і креатиніну. Назагал, токсична дія доксорубіцину з огляду на усі досліджувані показники була більш вираженою, ніж така дія похідних 4-тіазолідинонів. Введення щурам досліджуваних препаратів у вигляді комплексів із полімерним наноносієм істотно нормалізувало рівень загального протеїну, глюкози, сечовини і креатиніну, а також досліджуваних катіонів металів порівняно із впливом цих сполук у вільному стані. Іммобілізація як доксорубіцину, так і нових експериментальних протипухлинних чинників на полімерному наноносії знижує характерну для них високу загальну токсичність, зокрема нефротоксичність, що підтверджується нормалізацією низки біохімічних показників у сироватці крові щурів.

К л ю ч о в і с лов а: нефротоксичність, 4-тіазолідинони, доксорубіцин, полімерний нанорозмірний носій, концентрація метаболітів, сироватка крові щурів.

\section{БИОХИМИЧЕСКИЕ ПОКАЗАТЕЛИ НЕФРОТОКСИЧНОСТИ В СЫВОРОТКЕ КРОВИ КРЫС ПРИ ДЕЙСТВИИ НОВЫХ ПРОИЗВОДНЫХ 4-ТИАЗОЛИДИНОНОВ И ИХ КОМПЛЕКСОВ С ПОЛИЭТИЛЕНГЛИКОЛЬ- СОДЕРЖАЩИМ ПОЛИМЕРНЫМ НАНОРАЗМЕРНЫМ НОСИТЕЛЕМ}

Л. И. Кобылинская ${ }^{1}$ Д. Я. Гаврилюк ${ }^{1}$ Н. Е. Митина ${ }^{2}$, А. С. Заиченко ${ }^{2}$

Р. Б. Лесик ${ }^{1}$ Б. С. Зименковский,

P. С. Стойка

${ }^{1}$ Львовский национальный медицинский университет имени Данила Галицкого, Украина; e-mail: stoika@cellbiol.lviv.ua;

${ }^{2}$ Национальный университет «Львовская политехника», Украина;

${ }^{3}$ Институт биологии клетки НАН Украины, Львов

Основная задача исследования - сравнить влияние новых синтетических производных 4-тиазолидинонов (соединений 3882, 3288 и 3833) и доксорубицина (положительный контроль) в свободном состоянии и в комплексе с синтетическим полиэтиленгликольсодержащим наноразмерным носителем на биохимические показатели нефротоксичности в сыворотке крови крыс. Для этого определяли содержание общего протеина, глюкозы, мочевины, креатинина, катионов натрия, кальция, железа и анионов хлорида. Установлено, что после введения всех указаных соединений в сыворотке крови экспериментальных животных существенно возрастает по сравнению с контролем концентрация ионов натрия и хлоридов, а также глюкозы, а в случае действия доксорубицина - еще и катионов кальция. Вместе с тем, при этих условиях происходило достоверное снижение содержания общего протеина, мочевины и креатинина. Токсическое влияние доксорубицина на все исследуемые показатели было более выраженным, чем действие производных 4-тиазолидинонов. 
Введение крысам исследуемых соединений в виде комплексов с полимерным наноносителем существенно нормализировало уровень общего протеина, глюкозы, мочевины и креатинина, а также исследуемых катионов металлов по сравнению с влиянием этих соединений в свободном состоянии. Иммобилизация как доксорубицина, так и новых экспериментальных противоопухолевых соединений на полимерном наноносителе снижает характерную для них высокую общую токсичность, в частности нефротоксичность, что подтверждается нормализацией ряда биохимических показателей в сыворотке крови крыс.

Ключевы е слова: нефротоксичность, 4-тиазолидиноны, доксорубицин, полимерный наноразмерный носитель, концентрация метаболитов, сыворотка крови крыс.

\section{References}

1. Perry M. C., Doll D. C., Freter C. E. The Chemotherapy Source Book. Philadelphia: Walters Kluwer, Lippincott Williams \& Wilkins, 2012. 248 p.

2. Zimmerman H. J. Hepatotoxicity: The Adverse Effects of Drugs and Other Chemicals on the Liver. Lippincott Williams\&Wilkins, 1999. $789 \mathrm{p}$.

3. Kobylinska L. I., Havrylyuk D. Ya., Ryabtseva A. O., Mitina N. E., Zaichenko O. S., Zimenkovsky B. S., Stoika R. S. Study of rat blood serum biochemical indicators of cardiotoxic action of novel 4-thiazolidone derivatives and doxorubicin in complexes with polyethylenglycol-containing polymeric carrier. Ukr. Biochem. J. 2014; 86(6): 84-95. (In Ukrainian).

4. Kobylinska L. I., Havrylyuk D. Ya., Ryabtseva A. O., Mitina N. E., Zaichenko O. S., Lesyk R. B., Zimenkovsky B. S., Stoika R. S. Biochemical indicators of hepatotoxicity in blood serum of rats under the effect of novel 4-thiazolidinone derivatives and doxorubicin and their complexes with polyethyleneglycolcontaining nanoscale polymeric carrier. Ukr. Biochem. J. 2015; 87(2): 122-132.

5. Naughton C. A. Drug-induced nephrotoxicity. Am. Fam. Physician. 2008; 78(6): 743-750.

6. Pentiuk A. A., Voloshchuk N. I., Mashevska O. V. Nephrotoxicity drugs: clinical manifestations, pathophysiological mechanisms and approaches to treatment. Ration. Pharmacotherapy. 2009; (1(10)): 55-62. (In Ukrainian).

7. Derymedvid' L. V., Drogovoz S. M., Matveeva E. V., Kireyev I.V., Vereitinova V. P. Nephrotoxicity as the manifestation of drugs side effect. Ukr. Biopharm. J. 2014; 5(34): 59-61. (In Ukrainian).

8. Boiko N. M., Klyuchivska O. Yu., Kobylinska L. I., Havrylyuk D. Ya., Mitina N. Ye., Lesyk R. B., Zaichenko O. S., Stoika R. S. Vitality and morphology of tumor cells treated with 4-thiazolidinone derivatives immobilized on nanoscale polymer carrier. Biotechnologia Acta. 2015; 8(1): 39-48.

9. Chumak V. V., Panchuk R. R., Manko N. O., Havrylyuk D., Kobylinska L., Lesyk R., Zimenkovsky B. S., Stoika R. S. Comparative study of the cytotoxic properties of isatincontaining derivatives of 4-thiazolidinone with different structure toward human tumor cells in vitro. Studia Biologica. 2014; 8(2): 29-42. (In Ukrainian).

10. Havrylyuk D., Zimenkovsky B., Vasylenko O., Gzella A., Lesyk R. Synthesis of new 4-thiazolidinone-, pyrazoline-, and isatin-based conjugates with promising antitumor activity. $J$. Med. Chem. 2012; 55(20): 8630-8641.

11. Kobylinska L., Patereha I., Ryabtseva A. O., Mitina N. E., Zaichenko O. S., Kotsyumbas I., Zimenkovsky B. S., Stoika R. Study of acute toxicity of nanosized drug delivery system based on PEG comb-like carriers in white laboratory rats and mice. Modern Problems Toxicol., Food Chem. Safety. 2014; (3/4 (66/67)): 43-48. (In Ukrainian).

12. Kobylinska L., Havrylyuk D., Patereha I., Kotsyumbas I., Lesyk R., Stoika R. Study of acute toxicity and cumulative properties in rats of novel synthetic 4-tiazolidone derivatives with potential antineoplastic activity. Modern Problems Toxicol., Food Chem. Safety. 2013; 4(63): 38-43. (In Ukrainian).

13. Bharali D. J., Khalil M. Gurbuz M., Simone T. M., Mousa S. A. Nanoparticles and cancer therapy: a concise review with emphasis on dendrimers. Int. J. Nanomedicine. 2009; 4: 1-7.

14. Stefanov O. V. Preclinical Studies of Medicines. Methodological Recommendations. Kyiv, 2001. 527 p. (In Ukrainian).

15. European Convention for the Protection of Vertebrate Animals used for Experimental and 
Other Scientific Purposes (Strasbourg, March 18, 1986). - Available at http://zakon2.rada.gov. ua/laws/show/994_137 (In Ukrainian).

16. Establishing the order of conduct for preclinical studies of pharmaceutical substances and expert evaluation of materials from preclinical studies of pharmaceutical substances: Decree No 944 by Ministry of Health of Ukraine issued on 14.12.2009. Available at http://zakon.rada.gov. ua/cgi-bin/laws/main.cgi?nreg=z0053-10/

17. Arzamastsev E. V., Gouscova T. A., Berezovskaya I. V. Methodological Instructions on research of general toxicity of pharmaceuticals. Manual on experimental (preclinical) study of new pharmacological substances. Moscow, 2000. P. 18-26. (In Russian).

18. Riabtseva A., Mitina N., Boiko N., Garasevich S., Yanchuk I., Stoika R., Slobodyanyuk O., Zaichenko A. Structural and Colloidal-
Chemical Characteristics of Nanosized Drug Delivery Systems Based on Pegylated Comblike Carriers. Chem. Chem. Technol. 2012; 6(3): 291-295.

19. Senkiv Yu. V., Ryabtseva A. R., Heffeter P., Boyko N. M., Shlyakhtina E. A., Mitina N. E., Berger W., Zaichenko O. S., Stoika R. S. Immobilization of doxorubicin on the olygoelectrolytic polymeric carrier VEP-GMAPEG increases its and anticancer activity cellular uptake. Studia Biologica. 2012; 6(2): 5-16. (In Ukrainian).

20. Kamyshnikov V. S. Manual on Clinical Biochemical Investigations and Laboratory Diagnostics. Moscow: MEDpress-inform, 2004. 911 p. (In Russian).

Received 22.09.2015 